Faculty of Management, Rzeszów University

of Technology, Rzeszów, Poland

mc@prz.edu.pl

ORCID iD: https://orcid.org/0000-0002-2791-8252

PIOTR ZaWADA

Faculty of Social and Economic Sciences,

Institute of Economics and Finance

Cardinal Wyszyński University in Warsaw, Poland

p.zawada@uksw.edu.pl

ORCID iD: https://orcid.org/0000-0003-2817-9578

\title{
SOCIAL ECONOMY AND SOCIAL INNOVATIONS - AN IMPULSE FOR FURTHER, WIDER DISCUSSION
}

\section{INTRODUCTION}

The last decade, especially the recent economic, ecological and social changes, have made it clear that the task of all growth actors is not only to take care of the economic interest, but also - and perhaps above all - the social aspect that may allow the protection of social values (in existential) even in the most unpredictable situations. Social economy, solidarity economy and social innovation (Such-Pyrgiel, 2018, p. 40) are terms that have gained importance over the last decade and are of interest to both theoreticians and management practitioners. In the Polish scientific literature, the above-mentioned concepts are still - in the opinion of the authors - not sufficiently researched, therefore an attempt was made to analyze the Polish literature in this area, but - which is worth emphasizing - in a fundamental, fundamental aspect, in order to undertake a broader discussion on this topic. conceptual field by a wider group of researchers.

KEYWORDS: social economy, social innovation, innovation management, solidarity economy, corporate social responsibility 


\section{RESEARCH METHODS}

Science sees the world through theories (Heller, 2011, p. 44) and therefore the key, logical element of the development of science is the creation of a solid theoretical foundation, and one of the initial stages of the development of a given field is an attempt to organize knowledge or the beginning of the process of organizing knowledge in a new scope. In the case of no less work, the novelty are the concepts of social economy, social innovation and the economy of solidarity, which in the Polish scientific literature still - in the opinion of the authors - have not gained sufficient interest, especially in times of particular economic, ecological and social uncertainty. The method chosen in this research work was a (systematic) review of the literature in terms of the social economy, social innovation and the economy of solidarity. According to A. Booth, D. Papaioannou and A. Sutton, the process of systematic literature review generally consists of four stages (Roy, Byrne, Pickering, 2012, p. 351-363): search, evaluation, analysis and synthesis (Booth, Papaioannou, 2012, p. 1-279) and such a process was carried out as part of the author's research (Denyer, Neely, 2005, p. 131-135). The systematic review of the literature itself consists in the methodical selection of works, then their analysis through the prism of specific information (i.e. the purpose of the study) and presenting the results of these studies in the most transparent way possible (Hunt, 1997, p. 1-210), (Cooper, 1988, p. 104-126), (Cooper, Hedges, 2009, p. 5). The aim of the research was to create theoretical foundations for the concepts of social economy, solidarity economy and, to a small extent, social innovation, mainly based on Polish scientific literature.

\section{SOCIAL ECONOMY AND RELATED CONCEPTS THEORETICAL FOUNDATIONS}

Analyzing the market behaviour of business entities, a careful reader will notice the tendencies of business entities to maximize added value. The level of profitability of the enterprise is one of the most precise indicators that reflect the effects of employees' work in the company and the effectiveness of people occupying managerial positions. Work is the reason why nations get 
richer, Smith decided to make such an assessment, adding that "the wealth of each nation depends on two circumstances: first of all, on the skill, efficiency and knowledge with which it usually does its work; secondly, the ratio of those who work usefully to the number of those who do not" (Smith, 1954, p. 3).

The social economy emphasizes the support given to the disadvantaged who are not able to find a job on their own and thus gain the means to support themselves and their families. The necessary funds for such support come from the additional burden on the economies, which affects the profitability indicators of the tax-paying entities - business activity. On the other hand, political economics emphasizes actions aimed at maximizing economic efficiency, giving priority to economic freedom (Narski, 1997, p. 16). At this stage of the consideration, it is also worth mentioning the approach to economic issues presented by Grabski, for whom the first of the mentioned varieties of economics, i.e., social economy rather than political economy, was explained as the cause of the formation and development of social norms, thus justifying the place for organizational forms influencing the economy (Wójcik, 2002, p. 44). Grabski's approach to economic issues was also emphasized by the fact that the broader masses joined the social and economic life, which provided an opportunity to eliminate social stratification and was a counterbalance to treating economic activity limited to outstanding and enterprising individuals. The realization of social goals, as noted by this economist, also pointed to the need for a broader understanding of the motives of economic activity, which in turn led to a symbiosis of motivations, including the achievement of personal benefits, with elements of social, technological and even legal compulsion. In S. Grabski's concept of economics as such is a thread different from the universal subject covering production, exchange, division, consumption as a purposeful activity aimed at activities focused on the welfare of the nation. This interesting approach indicates Grabski's fascination with the social economy, to which he attributed a valuing dimension as opposed to the much poorer individual dimension. The isolation in the approach of liberal economics, including an individual focused on the implementation of the policy of increasing the profitability of the conducted activities, was in clear contradiction with the objectives that should guide economic activity, including the achievement of social goals. In the similar vein, Cz. Staszewski 
also spoke, who while analyzing economic issues pointed out that economy is an area of research focused on social farms and not on individuals, and it is reasonable to conclude that economy is a social science, which sooner or later must look at economic phenomena from the perspective of human activity in its entirety. The 50's caused S. Grabski to look at the ownership of the means of production from a slightly different perspective, the perspective that took into account the profitability of operating activity. Responsibility of the state should be to take care of such management conditions, within which there would be room for state assets and those belonging to units. The state should focus on the protection of the weaker and on managing affairs in such a way as to achieve the assumed economic stimulus. A particular achievement of S. Grabski should be considered the fact of combining theoretical economics with economic policy. According to this author, the central point of his deliberations was the recognition of the existence of a completely rational society, whose actions can be analyzed on the basis of the assumptions of social economy. This combination of economy, state and culture in Grabski's studies should be regarded as the beginning of the Polish economic thought on Social Economy.

\section{SOLIDATORY ECONOMY THEORETICAL FOUNDATIONS}

In the second half of the twentieth century in Poland there was also an intensive discussion in the area of economic issues focusing on solutions to social problems, but at that time politics and the use of Marxist ideology for analysis led to a dead end. This is the basic reason why the authors of the study decided to skip this period in their arguments concentrating on the contemporary approach to Social Economy, the economy with a completely different face. An interesting social experiment was the introduction to the political discourse of an economic alternative in the form of building a social and economic system taking into account the idea of justice. The change of paradigms and basic economic assumptions in postwar Germany resulted in the emergence of the first, remarkable Social Market Economy. This system had economic assumptions, albeit with very laudable goals, but was unable to resist the changes, forcing those in power to seek a way out of the cyclical economic crises that occurred and to maximize the social security 
of their citizens. Hence the proposal of changes in the approach to economic issues and the growing popularity of participatory economy. For example, M. Albert claimed that the time had come for consumer and employee councils to take responsibility for society (Albert, 1994, p. 227). The Participating Economy is the successor to the Solidarity Economy, and it incorporates in its assumptions a new dimension of society's functioning, builds new institutions and adheres to a different standard of management compared to the neoliberal model. The idea is to oppose the recognition of private benefits as the most important achievement in return for proposing to value its most important features: solidarity, diversity, self-government and ecology, to which activities in individual countries wishing to implement the principles of participatory economics should be subordinated. J.K. Galbraith, on the other hand, notes that the problem with implementing change is that the distribution of income generated in the economy depends on the distribution of power and the political system, which means that this distribution must take into account the interest of the general public and not only of the richest and those who currently hold power (Galbraith, 1999, p. 17). Such an approach takes into account the improvement of the quality of life and the increase of earnings, but not at the expense of the society as a whole, realized by a few. The aim of the activity conducted in the state is to maintain constant economic growth, production of goods and sale of services creating an open system based on the assumptions of functionality and socially accepted. Building a stable economic system, creating new jobs and maintaining economic growth is the basic goal of participatory economy. What is more, the above mentioned author pointed out that classical capitalism, similarly to socialism, cannot be considered acceptable from the social point of view because both did not take into account dignity as a social value. In J. Rifkin's studies, on the other hand, there are references to a broader view of the political, social and economic forces determining the shape of social life. The principle of subsidiarity and concern for sustainable development are activities aimed at effective social integration and improvement of social welfare. The most important elements that improve the quality of life are the primacy of relations within society, cultural diversity, sustainable development, respect for human rights, care for the environment and global cooperation (Rifkin, 
2005, p. 115) Such-Pyrgiel 2015, p 201. 13-33; Sitek 2016, p. 90 \& 146; SuchPyrgiel 2019, p. 92-93). This list is complemented by activities undertaken in social structures and aimed at building social capital, minimizing social exclusion and deepening social cohesion, ensuring joint responsibility and increasing social awareness. Empathy is called by this author a social binder, and when combined with respect for human rights, there is a chance to build a civil society with a very high potential of social capital and social sensitivity. F. Fukuyama, in turn, draws attention to the dysfunctions of state actions in the dimension of intervention aimed at minimizing social exclusion. This is not a direct reference to the European model of solidarity economy, but it shows that the issue of sustainable development and participation is also visible in American economic trends (Fukuyama, 2005, p. 77). J. Sachs also speaks in the same vein, drawing attention to the deficit of involvement of third sector organizations in some parts of the world in order to improve the fate of people who are not able to change their own situation (Sachs, 2006, p. 328). In view of the current market situation, the beginning of the global economic crisis and the as yet unknown effects of the Covid 19 pandemic on the world economy, it is worth considering a redefinition of macroeconomic assumptions that has accompanied mankind for so long that for many it may mean that there will be no change. The changes must take place mainly in the area of support for the third sector and institutional support, thanks to which social enterprises involved in the process of minimizing social exclusion and operating not for profit but for the realization of social goals, including the improvement of the welfare of rapidly impoverished societies, will be created.

\section{SUMMARY}

Social economy, solidarity economy and social innovation are terms that have gained importance over the last decade and are of interest to both theoreticians and management practitioners. In the Polish scientific literature, the mentioned concepts are still - in the opinion of the authors - not sufficiently researched, and therefore an attempt was made to analyze the Polish literature in this area, but in a basic, fundamental scope, in order to undertake a broader discussion in this conceptual field. 


\section{References}

Albert, M. (1994), Kapitalizm kontra kapitalizm, Kraków: „Znak” Signum. ISBN 837006289X.

Booth, D. Papaioannou, A. Sutton (2012), Systematic Approaches to a Successful Literature Review. Los Angeles: SAGE Publications. ISBN 9780857021359.

Cooper, H. (1998), Organizing knowledge syntheses: a taxonomy of literature reviews, Knowledge in Society 1. https://doi.org/10.1007/BF03177550.

Cooper, H., Hedges, L. (2009), Research synthesis as a scientific process. [w:] H. Cooper, L. Hedges, J. Valentine (red.), The Handbook of Research Synthesis and Meta-Analysis, New York: Russell Sage Foundation. ISBN 9780871541635.

Denyer, D., Neely, A. (2005), Introduction to special issue: innovation and productivity performance in the UK. International Journal of Management Reviews 5(3-4). ISSN 1460-8545.

Fukuyama, F. (2005), Budowanie państwa. Władza i ład międzynarodowy w XXI. Poznań: Rebis. ISBN 8373015957.

Galbraith, J., K. (1999), Godne społeczeństwo: program troski o ludność. Warszawa: Bellona. ISBN 8311089558.

Heller, M. (2011), Filozofia nauki. Kraków: Petrus. ISBN 9788378862512.

Hunt, M. (1997), How Science Takes Stock: the Story of Meta-Analysis,. New York: Russell Sage Foundation. ISBN 9780871543981.

Narski, Z. (1997), Ekonomia społeczna: zarys popularny. Toruń: Wydawnictwo Adam Marszałek. ISBN 8371741170.

Rifkin, E. (2005), Europejskie marzenie. Warszawa: Wydawnictwo Nadir. ISBN 839224530X.

Roy, S. (2012), A systematic quantitative review of urban tree benefits, costs, and assessment methods across cities in different climatic zones. Urban Forestry \& Urban Greening 11. ISSN 1618-8667.

Sachs, J. (2006), Koniec z nędzą, Zadanie dla naszego pokolenia. Warszawa: PWN. ISBN 9788301146603.

Sitek, M. (2016), Prawa (potrzeby) człowieka w ponowoczesności. Warszawa: Wyd. C.H. Beck. ISBN 9788325589226.

Smith, A. (1954), Badania nad natura i przyczynami bogacenia się narodów. Warszawa: PWN. 
Szejniuk, A. M. (2019). The work efficiency management (as a) - determinant of the development of modern organizations. Journal of Modern Science, 40(1), 285-303. https://doi.org/10.13166/jms/106020

Such-Pyrgiel, M. (2015). Rodzina i jakość życia we wspótczesnym społeczeństwie polskim. Zarys problematyki w: Bezpieczeństwo i jakość życia we współczesnym społeczeństwie polskim. Studium interdyscyplinarne, M. Sitek, M. Such-Pyrgiel, D. Przastek (red.), Wyd. WSGE, Józefów, pp. 13-33. ISBN 9788362753628.

Such-Pyrgiel, M. (2018). Nowe modele biznesu $w$ dobie transformacji cyfrowej w: Społeczne i ekonomiczne aspekty zarzadzania $w$ organizacjach przyszłości, Józefów: Wyd. WSGE. ISBN 9788362753956.

Such-Pyrgiel, M. (2019). Człowiek $w$ dobie cyfrowej transformacji. Studium socjologiczne, Toruń: Wyd. Adam Marszałek. ISBN 9788366220966.

Wójcik, S. (2002), Zapomniana polska ekonomia społeczna XX wieku. Lublin: Prace Wydziału Nauk Społecznych nr. 84 TN KUL. ISBN 8373060863. 